\title{
15 Relative (Un)Importanceof Introduced Animals as Pollinators and Dispersers of Native Plants
}

\author{
D. Kelly, A.W. Robertson, J.J. Ladley, S.H. ANDERSON \\ and R.J. MCKENZIE
}

\subsection{Introduction}

The island archipelagos of the Pacific are characterized by a recent pulse of species extinctions and declines following the wave of alien introductions brought by people (Steadman 1995). The invasion of mammalian predators in particular has had a devastating effect on keystone vertebrate pollinators and dispersers throughout the region (Cox 1983; Bell 1991; Rainey et al. 1995; Steadman 1997; McConkey and Drake 2002; Meehan et al. 2002). These losses raise the potential for flow-on effects disrupting mutualisms and threatening the plant species that depend on these mutualists (Janzen 1974; Kearns et al. 1998; Robertson et al. 1999; Cox and Elmqvist 2000; Sekercioglu et al. 2004). In some cases, other introduced species may replace the lost endemic species and partially restore the mutualism (Cox 1983; Lord 1991; Paton 1993; Ecroyd 1996). In Hawai'i, the vine ie'ie (Freycinetia arborea), which was originally pollinated by four endemic, now-extinct bird species, is currently pollinated by the introduced Japanese silvereye (Zosterops japonica; Cox 1983). In Tonga, the Pacific pigeon (Ducula pacifica), which colonized Tonga about the same time as people (Steadman 1997), is now the only pigeon present and is the largest avian frugivore, but it fails to match the gape of two extinct Ducula spp. As a result, several large-fruited species are now dependent on the sole remaining fruit bat (Pteropus tonganus) for dispersal (Meehan et al. 2002).

In New Zealand, introduced rats, stoats and other predators have caused the extinction of a large number of endemic vertebrates and the decline of many others, including birds (Bell 1991; Holdaway 1999), bats (Lloyd 2001), and lizards (Towns et al. 2001). Many of the extinct or declining birds were important frugivores, e.g., moa spp. (Dinornithiformes; all extinct) and 
kokako ${ }^{1}$ (Callaeas cinerea; in severe decline), or pollinators, e.g., stitchbirds (hihi, Notiomystis cincta; in severe decline; Atkinson and Millener 1991). Two species of short-tailed bat (family Mystacinidae) were both fruit and nectar feeders (Daniel 1976). The greater short-tailed bat (Mystacina robusta) is now extinct, and the lesser short-tailed bat (M. tuberculata) is in sharp decline (Lloyd 2001). Lizards have also suffered post-human declines in density (Towns et al. 2001), and it has been suggested that they may also have been important in pollination and dispersal (Whitaker 1987). However, work on offshore islands, where lizard densities remain high, has shown that although lizards do visit some flowers (Eifler 1995), they have limited ability to move between plants, and there is as yet no evidence that they played a significant role in pollination. The evidence is stronger for lizards as effective, albeit short-range, seed dispersers, as in the case of Coprosma propinqua (Wotton 2002).

The result of these species losses and declines is a reduced set of vertebrate dispersers and pollinators over much of the New Zealand mainland, but with a more intact fauna on some of the offshore islands that are predator-free. Of the species capable of dispersing the largest fruits (>14 mm diameter), only the New Zealand pigeon (kereru, Hemiphaga novaeseelandiae) remains (Clout and Hay 1989). Six plant species have fruits larger than this, and are thus vulnerable to the loss of kereru, which appears to also be in decline (Clout et al. 1995). Several other native birds take smaller fruit, particularly bellbirds (korimako, Anthornis melanura), tui (Prosthemadera novaeseelandiae), and silvereyes ${ }^{2}$ (Zosterops lateralis), along with stitchbirds and saddlebacks (tieke, Philesturnus carunculatus), which both also take fruit but now persist only on island bird sanctuaries. Four native bird species regularly visit flowers - bellbirds, tui, stitchbirds and silvereyes. Saddlebacks, kaka (Nestor meridionalis), and kea (Nestor notabilis) are occasional flower-visitors. All except silvereyes have been reduced in density and/or range. As far as is known, no extinct birds were significant flower-visitors (Atkinson and Millener 1991).

The native insect-pollinating fauna is fairly small and simple, with no hawkmoths, few "primitive" bees, and few butterflies (Dugdale 1975; Godley 1979). The most common invertebrate flower-visitorsare flies and moths. It is unclear whether these groups have suffered declines; no extinctions of native invertebrate pollinators are known (J. Dugdale, personal communication) but our knowledge of the prehuman and post-human insect pollinators is very sketchy, so losses may have gone unnoticed.

Bird names follow Heather and Robertson (1996).

The silvereye has been variously treated as native or introduced, because it first established in New Zealand in 1856. Since it apparently arrived without direct human assistance, we follow Heather and Robertson (1996) in calling it a recently arrived native. It is now widespread (Bull et al. 1985). 
There is increasing evidence that the losses of mutualists from much of New Zealand are having an effect on the reproduction of native plants. Mainland-island comparisons suggest that the fruit dispersal of nikau (Rhopalostylis sapida), kotukutuku (Fuchsia excorticata), and karo (Pittosporum crassifolium) is reduced or slowed by a lack of frugivores on the mainland (Anderson 1997; McNutt 1998). The fruit and seed production for six of seven species of bird-pollinated trees and shrubs has been shown to be pollen-limited at some mainland sites (Anderson et al. 2006). For instance, the red mistletoe (Peraxilla tetrapetala) is regularly pollen-limited at two South Island sites (Robertson et al. 1999; Kelly et al. 2004), and the climbing fuchsia (Fuchsia perscandens) also has very low fruit set at two sites near Christchurch (Montgomery et al. 2001). Both species are pollinated by bellbirds and tui, which at the study sites of both these plants are now uncommon and locally extinct, respectively.

Recent observations of relative abundances might suggest that introduced animals have now become quite important for pollination and dispersal of native plants in New Zealand. It is possible that they might offset the losses of native animals. Although there have been extinctions or severe range and density reductions in important native bird mutualists, a number of introduced plant visitors are now very widespread. The two most widespread of all bird species in New Zealand are the introduced chaffinch (Fringilla coelebs) and blackbird (Turdus merula; Bull et al. 1985), which visit flowers and fruits (Williams and Karl 1996; Ladley et al. 1997). In fact, 11 of the 15 most widespread birds in New Zealand are introduced (Bull et al. 1985). O'Donnell and Dilks (1994) and Burrows (1994) showed that blackbirds were important for dispersal of various native plants. Burrows said "had it not been for the naturalisation of silvereyes and blackbirds, last century, the link between birds and seed dispersal in Banks Peninsula forests would now be very tenuous" (Burrows 1994, p. 177). Introduced feral bumblebees can be found throughout the country, and honeybees are "probably one of the most common and continuously present insects" (Donovan 1980, p. 109). Butz Huryn (1995) provided a list of 188 native plant species whose flowers are visited by honeybees.

However, a quantitative assessment of the importance of introduced animals has not previously been attempted. There are three possible measures of the importance of introduced species. The least accurate is based on presence/absence - the percentage of introduced species in lists of all visitors to flowers or fruit. The second is quantitative, based on the percentage of visits made by various species. The third and most accurate is effectiveness, which takes into account both frequency and efficacy of visits (e.g., the proportion of flowers successfully pollinated by a particular animal). There are preliminary indications from quantitative information that introduced dispersers may be less important than a "species list" approach suggests: introduced birds around Nelson were more likely than native birds to feed on fruits of introduced plants (Williams and Karl 1996). 
The aim of this review is to evaluate the relative importance of introduced animals for pollinating and dispersing native plants, based mainly on the frequency of visits to flowers and fruits. Ideally, this assessment would be based on effectiveness, but there are few data on the effectiveness of individual animals as pollinators or dispersers (e.g., Robertson et al. 2005). Hence, a comprehensive review at that level is not yet possible.

\subsection{Approach}

We use the term "mutualist" to mean "animal pollinator of flowers or disperser of seeds". We use "flower-visitor" to mean an animal recorded approaching flowers. Such animals may be effective pollinators, may be partial or complete robbers of nectar and/or pollen, or may be searching for other foods among the flowers, with or without incidental pollination. Only when there is clear evidence that the visitor is not achieving any pollination (e.g., kereru eating flowers of a range of different plant species; O'Donnell and Dilks 1994) do we exclude those data. Similarly, for "fruit-visitor" we include all animals visiting fruit, although some may be partial or complete seed predators (e.g., most parrots) or incidental visitors.

To estimate the relative numerical importance of introduced animals, we collated all published studies where the percentages of visits made by all different taxa to native plants were given. Studies that listed the species visiting flowers or fruits without numerical estimates of their importance (e.g., Primack 1983), or that listed native flowers or fruits in the diet of introduced animals (e.g., Butz Huryn 1995; Williams and Karl 1996) were not included. We supplemented the literature with our own unpublished data. Generally, the proportion of "visits" made by each group was measured by the relative length of time spent foraging on fruits and flowers.

In a few cases, several related plants were grouped together (e.g., climbing Metrosideros spp.). Bird visitors to plants were identified to species level. In most cases, invertebrate flower-visitors were identified only to broad taxonomic groups, some of which (e.g., Diptera, Coleoptera) may contain a mixture of native and introduced species, although these groups are almost certainly dominated by native species. Bombus spp., Apis mellifera and Vespula spp. were always separated from other flower-visitors.Data in O'Donnell and Dilks (1994) were presented as percentages by columns (birds); we multiplied up to counts, then calculated percentages by rows (plants), excluding plants with fewer than 10 observations. Our own data were obtained either by direct or video observation of groups of plants during the flowering or fruiting season (see Robertson et al. 1999 for details). The data presented here are the proportion of visits made for site-species combinations. Where data from more 
Table 15.1 Bird visitors to flowers of native plants, mostly forest species (\% of all visits by each bird). Birds are arranged by numerical importance within category (native or introduced). Kereru visit flowers to eat them, so they cannot effect pollination and are not listed ${ }^{\mathrm{a}}$

\begin{tabular}{|c|c|c|c|c|c|c|c|c|c|c|c|}
\hline \multirow[t]{2}{*}{ Plant sp. } & \multirow[t]{2}{*}{ Site, ref. } & \multicolumn{6}{|c|}{ Native birds } & \multicolumn{4}{|c|}{ Introduced birds } \\
\hline & & bel & sil & tui & sti & kak & Other & spa & cha & Other & Total $^{\mathrm{b}}$ \\
\hline Alefla & Cra, 1 & 30 & 70 & 0 & 0 & 0 & & 0 & 0 & & 0 \\
\hline Dysspe & Tir,2 & 48.5 & 3.0 & 45.5 & 1.2 & 0 & sad 1.8 & 0 & 0 & & 0 \\
\hline Dysspe & Wen, 2 & 0 & 0 & 100 & 0 & 0 & & 0 & 0 & & 0 \\
\hline Fucexc & $\mathrm{AhS}, 1$ & 2.7 & 97.3 & 0 & 0 & 0 & & 0 & 0 & & 0 \\
\hline Fucexc & Aka, 1 & 44.2 & 54.4 & 0.5 & 0 & 0 & & 0 & 0.3 & $\operatorname{ros} 0.5$ & 0.8 \\
\hline Fucexc & Koh, 1 & 1.7 & 97.9 & 0 & 0 & 0 & & 0.4 & 0 & & 0.4 \\
\hline Fucexc & Hin, 1 & 17.5 & 82.5 & 0 & 0 & 0 & & 0 & 0 & & 0 \\
\hline Fucexc & $\mathrm{MtF}, 1$ & 63.5 & 33.2 & 3.3 & 0 & 0 & & 0 & 0 & & 0 \\
\hline Fucexc & Pre, 1 & 15.3 & 16.6 & 68.1 & 0 & 0 & & 0 & 0 & & 0 \\
\hline Fucexc & Riti, 1 & 69.4 & 0 & 30.6 & 0 & 0 & & 0 & 0 & & 0 \\
\hline Fucexc & $\mathrm{Rku}, 1$ & 0 & 0 & 100 & 0 & 0 & & 0 & 0 & & 0 \\
\hline Fucexc & Rroa, 1 & 63.3 & 0 & 36.7 & 0 & 0 & & 0 & 0 & & 0 \\
\hline Fucexc & Rua, 1 & 5.0 & 93.4 & 1.7 & 0 & 0 & & 0 & 0 & & 0 \\
\hline Fucexc & Win, 3 & 37.1 & 43.9 & 13.0 & 0 & 5.7 & kea 0.2 , fan 0.1 & 0 & 0 & & 0 \\
\hline Gnluc & Tir, 2 & 51.1 & 14.9 & 14.9 & 0 & 0 & par19.1 & 0 & 0 & & 0 \\
\hline Metexc & Tir, 2 & 36.5 & 7.8 & 50.4 & 0.3 & 0 & par1.7, sad1.8,whi 1.0 & 0 & 0 & myn 0.3 , sta 0.3 & 1.6 \\
\hline Metexc & Wen, 2 & 0 & 16.2 & 36.5 & 0 & 0 & & 37.9 & 0.6 & $\operatorname{ros} 1.7$, myn 2.5 , sta 4.7 & 47.3 \\
\hline Met spp & Win, 3 & 41.4 & 28.8 & 23.0 & 0 & 6.9 & & 0 & 0 & & 0 \\
\hline Metumb & Win, 3 & 24.5 & 28.9 & 15.2 & 0 & 17.5 & kea 13.9 & 0 & 0 & & 0 \\
\hline Per spp & Win, 3 & 9.1 & 4.0 & 3.7 & 0 & 80.5 & yel2.7 & 0 & 0 & & 0 \\
\hline Percol & Waip, 1 & 98.7 & 0 & 1.3 & 0 & 0 & & 0 & 0 & & 0 \\
\hline Percol & Wak, 1 & 3 & 0.2 & 96.7 & 0 & 0 & & 0 & 0 & & 0 \\
\hline Pertet & Bel, 1 & 0 & 0 & 100 & 0 & 0 & & 0 & 0 & & 0 \\
\hline Pertet & Boy, 1 & 95.3 & 0 & 4.7 & 0 & 0 & & 0 & 0 & & 0 \\
\hline Pertet & $\mathrm{Cra}, 1$ & 94.4 & 5.5 & 0 & 0 & 0 & & 0 & 0.1 & & 0.1 \\
\hline Pertet & $\mathrm{Egl}, 1$ & 98.5 & 0 & 1.5 & 0 & 0 & & 0 & 0 & & 0 \\
\hline
\end{tabular}




\begin{tabular}{|c|c|c|c|c|c|c|c|c|c|c|c|}
\hline \multirow{2}{*}{ Plant sp. } & \multirow[t]{2}{*}{ Site, ref. } & \multicolumn{4}{|c|}{ Native birds } & \multicolumn{6}{|c|}{ Introduced birds } \\
\hline & & bel & sil & tui & sti & kak & Other & spa & cha & Other & Total $^{\mathrm{b}}$ \\
\hline Pertet & Lit, 1 & 100 & 0 & 0 & 0 & 0 & & 0 & 0 & & 0 \\
\hline Pertet & Oha, 1 & 41.8 & 25.8 & 0 & 0 & 0 & & 7.4 & 25.0 & & 32.4 \\
\hline Photen & Cas, 4 & 52.5 & 45.8 & 0 & 0 & 0 & & 0 & 0 & sta 1.70 & 1.7 \\
\hline Photen & Por, 4 & 20.8 & 78.7 & 0 & 0 & 0 & & 0 & 0 & sta 0.60 & 0.6 \\
\hline Pitcra & Tir, 2 & 81.1 & 0 & 18.9 & 0 & 0 & & 0 & 0 & & 0 \\
\hline Pitcra & Wen, 2 & 0 & 81.0 & 14.3 & 0 & 0 & & 4.8 & 0 & & 4.8 \\
\hline Psearb & Mah, 2 & 0 & 12.5 & 87.5 & 0 & 0 & & 0 & 0 & & 0 \\
\hline Psearb & Tir, 2 & 79.2 & 1.0 & 17 & 0.7 & 0 & whi 2.1 & 0 & 0 & & 2.1 \\
\hline Psecra & Win, 3 & 40.5 & 39.3 & 20.2 & 0 & 0 & & 0 & 0 & & 0 \\
\hline Rhasol & Lit, 2 & 0 & 0 & 0 & 100 & 0 & & 0 & 0 & & 0 \\
\hline Rhasol & Tir, 2 & 52.6 & 0 & 0 & 47.4 & 0 & & 0 & 0 & & 0 \\
\hline Rhasol & Wen, 2 & 0 & 100 & 0 & 0 & 0 & & 0 & 0 & & 0 \\
\hline Sopmic & $\mathrm{AhV}, 1$ & 2.1 & 96.1 & 0 & 0 & 0 & & 0.2 & 1.7 & & 1.9 \\
\hline Sopmic & Kow, 1 & 37.9 & 0 & 62.1 & 0 & 0 & & 0 & 0 & & 0 \\
\hline Sopmic & Poh, 1 & 32.3 & 62 & 5.6 & 0 & 0 & & 0 & 0 & & 0 \\
\hline Sopmic & Rroa, 1 & 67.5 & 0 & 32.5 & 0 & 0 & & 0 & 0 & & 0 \\
\hline Sopmic & Tai, 1 & 0 & 36.6 & 0 & 0 & 0 & & 27.9 & 35.4 & & 63.3 \\
\hline Sopmic & Tir, 2 & 17.0 & 0 & 83.0 & 0 & 0 & & 0 & 0 & & 0 \\
\hline Sopmic & Uni, 1 & 0 & 18.6 & 0 & 0 & 0 & & 81.4 & 0 & & 81.4 \\
\hline Sopmic & Waim, 1 & 0 & 98.8 & 0 & 0 & 0 & & 0 & 1.2 & & 1.2 \\
\hline Sopmic & Wen, 2 & 0 & 12.7 & 87.3 & 0 & 0 & & 0 & 0 & & 0 \\
\hline Sopmic & Wen, 1 & 0 & 1.7 & 98.3 & 0 & 0 & & 0 & 0 & & 0 \\
\hline Soppro & Kait, 1 & 0 & 100 & 0 & 0 & 0 & & 0 & 0 & & 0 \\
\hline Vitluc & Tir, 2 & 79.7 & 1.9 & 13 & 3.9 & 0 & & 0 & 0 & ros 1.44 & 1.4 \\
\hline Vitluc & Wen, 2 & 0 & 55.5 & 24.7 & 0 & 0 & & 0 & 0 & $\operatorname{ros} 10.5$, myn 9.4 & 19.9 \\
\hline Weirac & Win, 3 & 9.8 & 62.5 & 13.6 & 0 & 14.0 & & 0 & 0 & 0 & 0 \\
\hline Mean & & 32 & 31.3 & 25.5 & 3.0 & 2.4 & & 3.1 & 1.2 & & 5.0 \\
\hline
\end{tabular}


a Plant species codes are the first three letters of genus and species names. Full species names are: Alepis flavida, Dysoxylum spectabile, Fuchsia excorticata, Geniostoma lucida, Metrosideros excelsa, Metrosideros spp. (vines), Metrosideros umbellata, Peraxilla spp. (colensoi and tetrapetala), Peraxilla colensoi, Peraxilla tetrapetala, Phormium tenax, Pittosporum crassifolium, Pseudopanax arboreus, Pseudopanax crassifolius, Rhabdothamnus solandri, Sophora microphylla, Sophoraprostrata, Vitex lucens, Weinmannia racemosa. Bird species codes are the first three letters of the common name. Full names (with overall mean where not given above) are: bellbird, silvereye,tui, stitchbird, kaka, parakeet spp. $0.4 \%$ (largely yellow-crowned), kea 0.3, saddleback 0.1, whitehead 0.1, yellowhead 0.1, fantail <0.1, house sparrow, chaffinch, eastern rosella 0.3, mynah 0.2, starling 0.1. Full site names as in original reference are: Ahuriri Summit, Ahuriri Valley, Akatarawa, Belgrove, Boyle, Cass, Craigieburn, Eglinton,

Hinewai, Kaituna Valley, Kohitere, Kowhai Point, Little Barrier, Mahurangi, Mt. Fyffe, Ohau, Pohangina, Port Hills, Pretty Bridge, Rotoiti, Rotokura, Rotoroa, Ruahine, Taihape, Tiritiri, University of Canterbury, Waimakariri, Waipori, Wakefield, Wenderholm, Windbag. References: 1 Robertson et al. (1999) and unpublished; 2 Anderson (1997);3 O'Donnell and Dilks (1994); 4 Tisch (1996)

Total visitation by introduced species 
than one season were available for a site, we averaged all seasons to provide a single value for that site.

\subsection{Bird Flower-Visitors}

We found 52 cases covering 18 native plant species from 31 sites throughout New Zealand, visited by 16 bird species of which five (31\%) were introduced (Table 15.1). In 36 cases (69\%), there were no introduced birds recorded visiting flowers. The most often recorded introduced bird, the house sparrow (Passer domesticus), made only $3.1 \%$ of all visits, and all introduced species together totaled only $5 \%$. In contrast, the endemic tui and bellbird and the native silvereye combined made $89 \%$ of all visits. The average for the endemic stitchbird was as high as for sparrows, despite stitchbirds being present at only two island sites, where 10 of the 52 cases were measured. In these 10 cases, stitchbirds made $15.3 \%$ of all flower visits. The key variation among cases was the percentage of flower visits by silvereye versus all other native birds (Fig. 15.1). In only five cases did introduced birds contribute more than

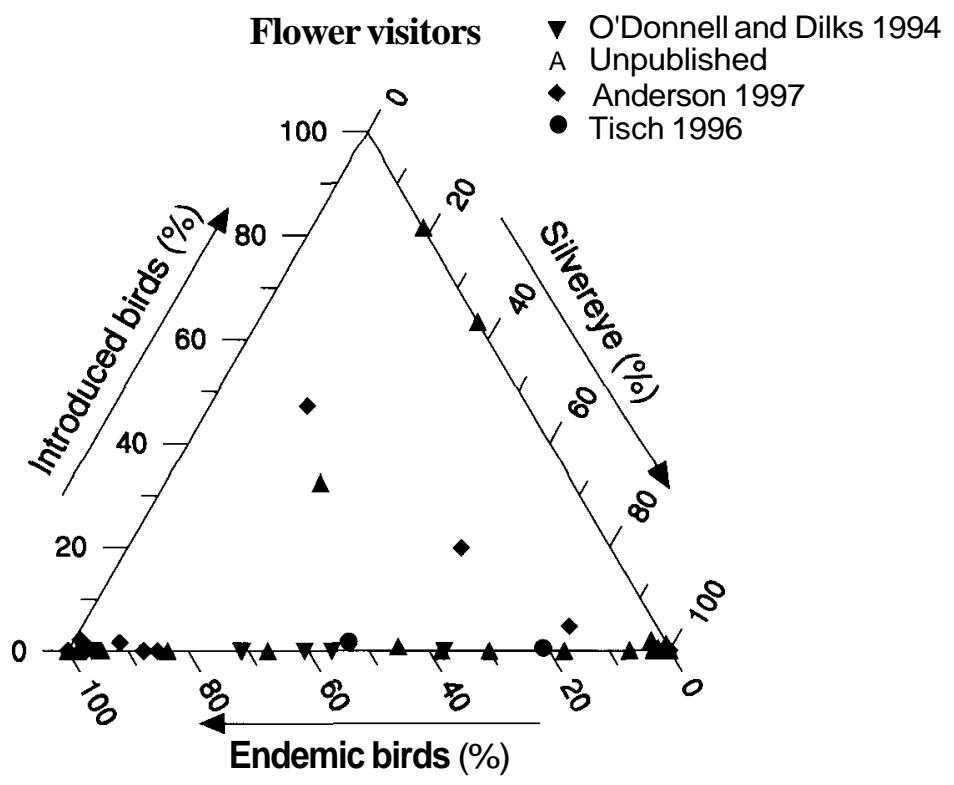

Fig. 15.1 Percentage of avian flower visits made by introduced birds, native silvereyes, and all other native birds (nearly all endemic), in $\mathbf{5 2}$ quantitative studies on $\mathbf{1 8}$ native plant species. The greater the importance of introduced birds, the higher the data point will be above the baseline. Sites in the bottom left are dominated by endemic birds, those in the bottom right by silvereyes and in the top by introduced birds. See Table $\mathbf{1 5 . 1}$ for a full listing of bird and plant species 
$5 \%$ of visits; the most important introduced flower-visitors at these sites were chaffinches and sparrows (Table 15.1). All five cases were from landscapes that have been very heavily modified with land use that is now largely urban or pastoral.

\subsection{Bird Fruit-Visitors}

The $\mathbf{3 9}$ cases covered $\mathbf{3 2}$ native plant species from $\mathbf{1 0}$ sites from South Westland to Auckland, although two-thirds of the cases came from the Westland site. The plants were visited by 22 bird species, seven of which (32\%) were introduced (Table 15.2). However, 15 of the bird species (including six of the introduced species) were minor fruit-visitors, each responsible for $<1 \%$ of total visits. Four native species (silvereye, bellbird, tui, and kereru) accounted for $83.7 \%$ of all visits. There were more cases (than for pollination) with nontrivial contributions by introduced birds (Fig. 15.2), with nine cases (23\%) having more than $5 \%$ of visits by exotics. However, 22 cases $(56 \%)$ had no

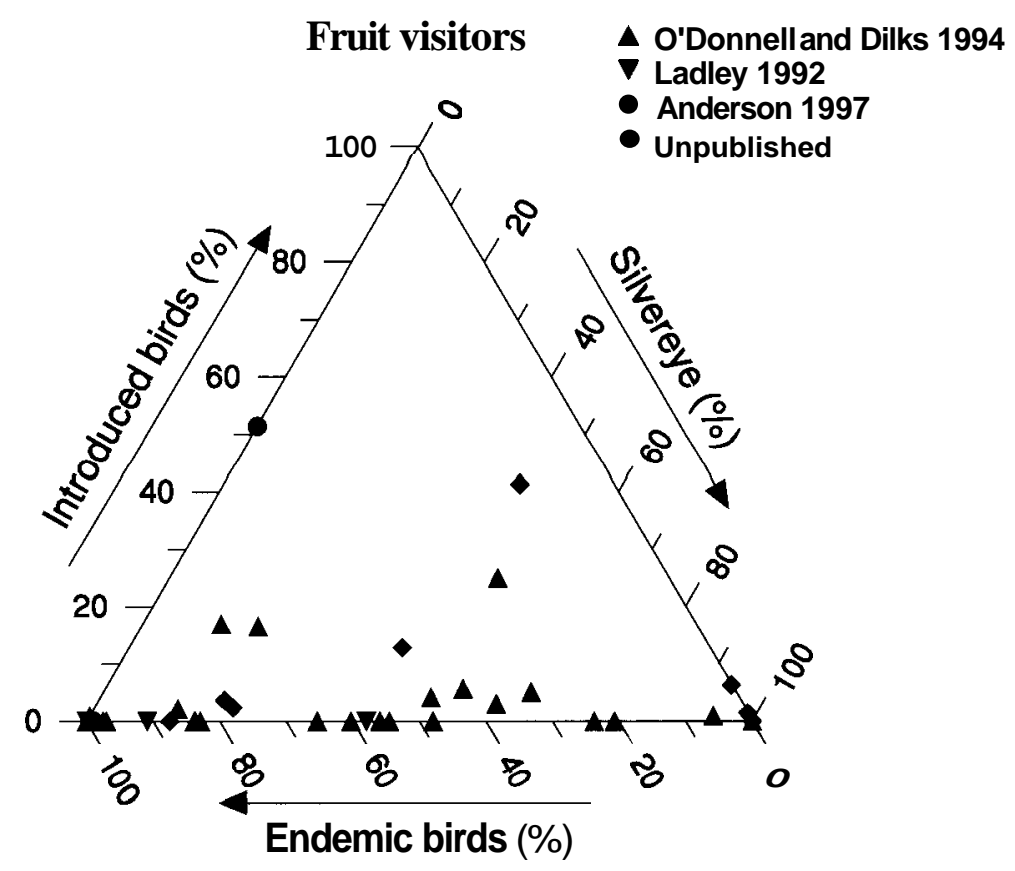

Fig. 15.2 Percentage of visits to fruits on 32 native plant species made by introduced birds, native silvereyes, or all other native birds (nearly all endemic) in $\mathbf{3 9}$ studies. The greater the importance of introduced birds, the higher the data point will be above the baseline. See Table $\mathbf{1 5 . 2}$ for a full listing of bird and plant species 
Table 15.2 Bird visitors to fruits of native plants, mostly forest species (\% of all visits by each bird). Birds are arranged by numerical importance within category (native or introduced)a






\begin{tabular}{|c|c|c|c|c|c|c|c|c|c|c|c|c|c|}
\hline Pitcra & Wen, 3 & 93.8 & 0 & 0 & 0 & 0 & 0 & & 3.1 & 0 & 3.1 & & 6.3 \\
\hline Podhal & Win, 2 & 2.9 & 3.3 & 0 & 0 & 73.8 & 0 & par 20.0 & 0 & 0 & 0 & & 0.0 \\
\hline Prufer & Win, 2 & 0 & 0.6 & 93.7 & 0.4 & 4.5 & 0 & & 0.9 & 0 & 0 & & 0.9 \\
\hline Psearb & Pih, 3 & 100 & 0 & 0 & 0 & 0 & 0 & & 0 & 0 & 0 & & 0.0 \\
\hline Psearb & Tir, 3 & 12.4 & 21 & 0 & 6.8 & 0 & 35.3 & par 0.9 , whi 11.4 , sti 12.1 & 0 & 0 & 0 & & 0.0 \\
\hline Psearb & Wtak, 3 & 98.6 & 0 & 0 & 0 & 0 & 0 & & 0 & 0 & 0 & myn 1.4 & 1.4 \\
\hline Psecra & Win, 2 & 53.7 & 7.3 & 19.2 & 0 & 6.2 & 0 & tom3.5 ,bro1.7, gre2.8 & 2.3 & 0 & 3.3 & & 5.6 \\
\hline Psewcol & Win, 2 & 17.1 & 13.6 & 69.4 & 0 & 0 & 0 & & 0 & 0 & 0 & & 0.0 \\
\hline Rauedg & Win, 2 & 45.4 & 7.9 & 0 & 10.4 & 7.8 & 0 & rif20.6, fan5.2, tom2.7 & 0 & 0 & 0 & & 0.0 \\
\hline Rausim & Win, 2 & 49.6 & 0.6 & 36.5 & 0 & 0 & 0 & rif3.1, tom0.6, bro2.1, gre3 & & 3.8 & 0 & 0.5 & 4.2 \\
\hline Ripsca & Win, 2 & 2.5 & 22.6 & 66.6 & 5.5 & 2.8 & 0 & & 0 & 0 & 0 & & 0.0 \\
\hline Rub spp & Win, 2 & 100 & 0 & 0 & 0 & 0 & 0 & & 0 & 0 & 0 & & 0.0 \\
\hline Shedig & Win, 2 & 79.3 & 0 & 19.7 & 1.0 & 0 & 0 & & 0 & 0 & 0 & & 0.0 \\
\hline Tupant & Wnui, l & 0 & 100 & 0 & 0 & 0 & 0 & & 0 & 0 & 0 & & 0.0 \\
\hline Mean & & 37.8 & 19.0 & 17.2 & 9.7 & 4.3 & 3.1 & & 3.9 & 0.5 & 0.4 & & 5.1 \\
\hline
\end{tabular}

a All codes (except references) are as for Table 15.1, with these additions. Plant species: Aristotelia serrata,Ascarina lucida, Carpodetus serratus,

Coprosma foetidissima, $C$. robusta, . rotundifolia, . spp. (divaricates), Coriaria arborea, Dacrydium cupressinum, Dacrycarpus dacrydioides, Griselinia littoralis, Heydcarya arborea, Ileostylus micranthus, Myrsine australis, M. divaricata, Neomyrtus pedunculata, Podocarpus hallii, Prumnopitys ferruginea, Pseudowintera colorata, Raukaua (was Pseudopanax) edgerlyi, Raukaua simplex, Ripogonum scandens, Rubus spp., Scheflera digitata, Tupeia antarctica. Bird species (and means): parakeets $0.8 \%$, whitehead 0.8, rifleman 0.6, stitchbird 0.5, fantail 0.4, tomtit 0.4, brown creeper 0.2, grey warbler 0.2 , yellowhead $<0.1$, song thrush 0.2 , mynah 0.1 , starling 0.1 , redpoll <0.1. Site names: Piha, Waitakere, Wainui. References: 1 Ladley (1994);2 O'Donnell and Dilks (1994);3 Anderson (1997); 4 own unpublished data

b Total visitation by introduced species 
introduced fruit-visitors, and the average contribution by exotics was only $5 \%$. By far the most important introduced bird was the blackbird, responsible for $3.9 \%$ of all visits ( $76 \%$ of introduced bird visits), but the endemic saddleback was almost as high in overall contribution to visits (Table 15.2, Fig. 15.2), despite being extant at only one study site (Tiritiri Matangi Island) where four plant species were studied. Saddlebacks made $30.4 \%$ of all visits to these four species.

\subsection{Invertebrate Flower-Visitors}

We found 15 cases for insect visitors to 12 plant species (Table 15.3). Of the introduced insects, one group (the Hymenoptera) are important as flowervisitors to native plants. These introduced hymenopterans (the honeybee Apis mellifera, four bumblebees Bombus spp., and two wasps Vespula vulgaris and $\boldsymbol{V}$. germanica) have achieved greater penetration into native systems (Fig. 15.3) than was the case for birds. In only three of the 15 cases were no vis-

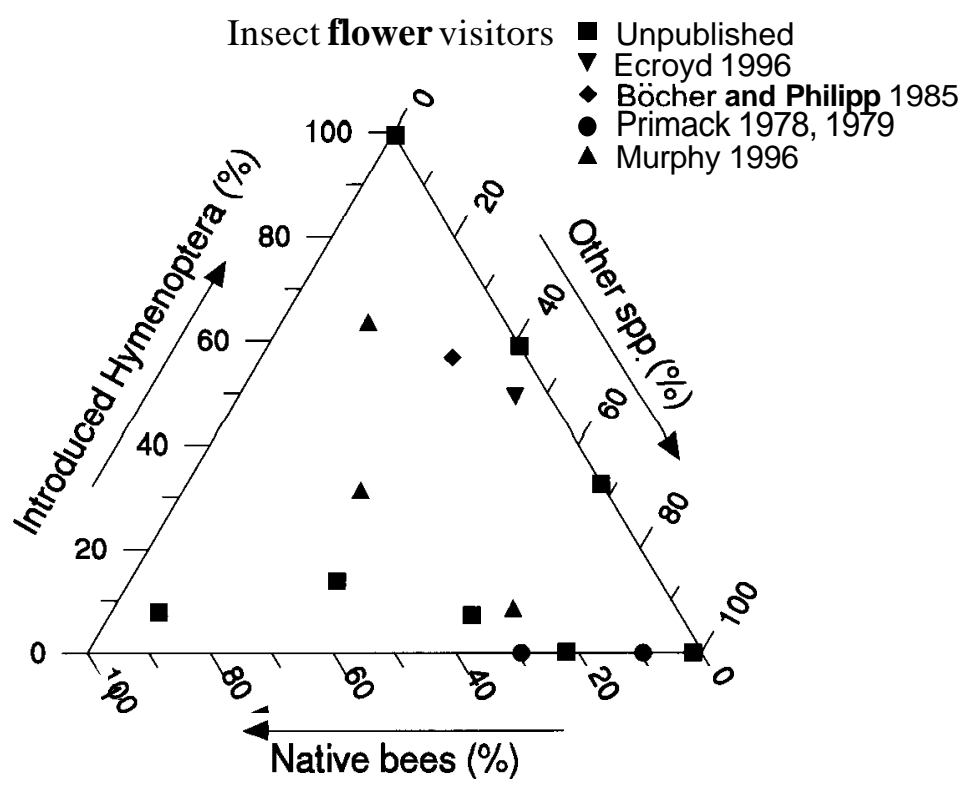

Fig. 15.3 Percentage of visits to flowers of $\mathbf{1 2}$ native plant species made by introduced bees and wasps, native bees, or all other invertebrates (mainly Diptera, nearly all native) in 15 studies. The greater the importance of introduced Hymenoptera, the higher the data point will be above the baseline. See Table $\mathbf{1 5 . 3}$ for a full listing of insect and plant species 
Table 15.3 Insect visitors to flowers of native plants (\% of all visits by insects). Insects are arranged by category (native or introduced)a

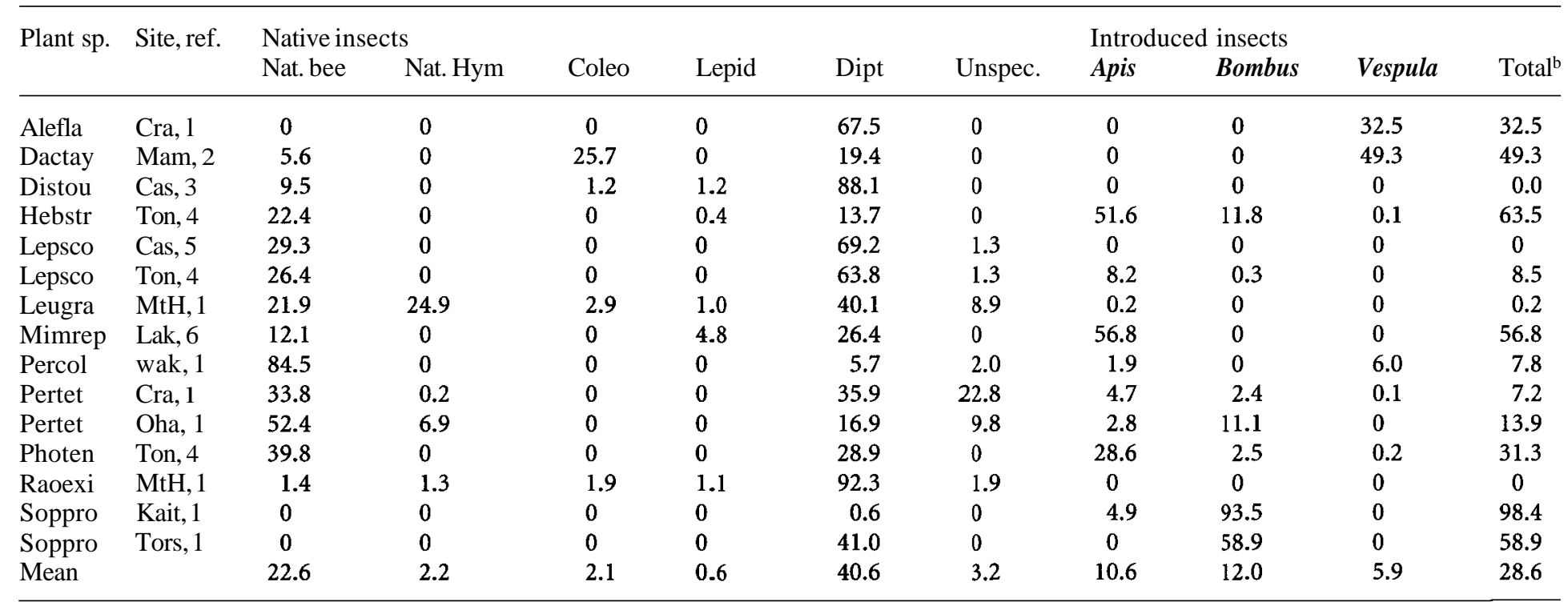

a All codes (except references) as for Tables 15.1 and 15.2, with these additions. Plant species: Dactylanthus taylorii, Discaria toumatou, Hebe stricta, Leptospermum scoparium, Leucogenes grandiceps, Mimulus repens, Raoulia eximia. Species with entomophilous flowers are Distou, Hebstr, Lepsco, Leugra, Mimrep and Raoexi. Insect visitor taxa as follows: native bees, other native Hymenoptera, Coleoptera*, Lepidoptera*, Diptera*, unspecified* (includes unidentified visitors and taxa not separately listed), Apis mellifera, Bombus spp., Vespula spp. Groups marked * are mainly native but may include some introduced species. Sites: Lake Ellesmere, Mamaku, Mt. Hutt, The Tors, Tongariro. References: 1 own unpublished data; 2 Ecroyd (1996);3 Primack (1979); 4 Murphy (1996);5 Primack (1978);6 Bocher and Philipp (1985)

b Total visitation by introduced species 
its from introduced bees and wasps recorded, whereas in five cases these insects made more than half of the visits. The rate of visitation by honeybees may depend on the distance to commercial hives (e.g., close at Tongariro, and distant at Mt. Hutt). In some cases, visits from native vertebrates, which are not shown in Fig. 15.3, may be more important than those from insects (e.g., bats to Dactylanthus; Ecroyd 1996), but in other cases (e.g., Hebe stricta, one site of Sophora prostrata), no vertebrates were recorded as visitors. Overall, introduced Hymenoptera were responsible for $29 \%$ of the visits made by insects, which represents a level of relative visitation to flowers that is five times greater than that shown by introduced birds. However, only half of these 12 plant species have"entomophilous"flowers (Table 15.3), and the mean level of visitation by introduced hymenopterans for the entomophilous species was somewhat lower (18\%).

\subsection{Implications of Findings}

The key result from the data is the relatively low importance of introduced animal mutualists, especially birds. Their quantitative contribution to flower and fruit visits (c 5\%) is much lower than would be expected from a summary of species lists of plant visitors (c $33 \%$ ).

Among introduced birds, only blackbirds (for fruit), chaffinches (for flowers), and sparrows (for flowers) make any appreciable percentage of visits, but even the uncommon endemic kaka is more important than any of these widespread and abundant introduced species (Fig. 15.4). Plant-bird mutualisms are now almost entirely dependent on four native birds, with the silvereye and bellbird predominant. Tui make up slightly fewer visits but are significant as the longest-billed species, which are important to long-tubed flowers such as Sophora spp. (Anderson 1997). Kereru are important for dispersal of fruits too large (>14 mm) for the other birds to swallow (Clout and Hay 1989), although their overall contribution as mutualists is reduced by their negative role in pollination - they eat the flowers of at least six native plants (O'Donnell and Dilks 1994).

However, there are several limitations to these data. Relative visitation rates do not tell us about the absolute level of visitation to plants, which may be too low for adequate pollination or dispersal. In some cases, the relative contribution of exotic birds rises because the absolute contribution of native birds falls (e.g., P.tetrapetala at Ohau; Ladley et al. 1997; Robertson et al. 1999), but this does not mean that the exotic birds are providing adequate service. Also, the effectiveness of different animals as pollinators and dispersers varies widely. Flower-visitors may be partial or complete nectar-robbers, which can reduce the attractiveness of flowers to legitimate pollinators (Irwin and Brody 1999), or cause direct mechanical damage to flowers (Anderson 2003). Fruit-visitors 




Fig. 15.4 Overall mean contribution by different bird species to flower visits and fruit visits on native plants throughout New Zealand. Introduced birds are marked with triangles, native birds with circles. Kereru are marked as doing zero pollination, but actually have a negative effect on pollination by eating flowers (see text)

may be partial or complete seed-predators (e.g., native parrots; O'Donnell and Dilks 1994), or may eat the fruit flesh without moving fruits away from the parent (e.g., fruit bats; Rainey et al. 1995).

Direct measures of mutualist effectiveness in New Zealand are scarce but some facts are known at a qualitative level. Short-beaked birds (silvereye, sparrow, chaffinch) are unable to access the nectar in long-tubed native flowers (Sophora spp., Peraxilla spp., Fuchsia excorticata, Rhabdothamnus solandri), and act primarily as nectar-robbers (Delph and Lively 1985; Anderson 1997; Ladley et al. 1997). Short-tongued bumblebees (Bombus terrestris) rob nectar from long-tubed flowers by biting holes in the corolla (Donovan 1980). Honeybees take nectar from the base of larger flowers (Anderson 1997). Birds with small gapes (especially silvereyes) are unable to swallow larger fruits (Clout and Hay 1989), though by pecking at the flesh they may disperse some seeds of small-seeded large-fruited species such as Fuchsia excorticata (Burrows 1994). In general, the effectiveness of most visitors to flowers and fruit is scarcely studied. However, special emphasis should be placed on longtongued visitors (especially tui, and to a lesser extent bellbirds) to long-tubed flowers, and on large-gaped visitors (especially kereru) to large fruit, as particularly important. 
Another gap concerns the role of introduced mammals in pollination and seed dispersal. NewZealand has only two plants apparently adapted to bat pollination, and for these, rats (Rattus spp.) or possums (Trichosurus vulpecula) may be partial substitutes (Lord 1991; Ecroyd 1996). There are no indications that mammals are important in pollinating other native plants. Contributions by mammals to dispersal are less clear. Rats are largely seed predators but effect some dispersal of small-seeded species (Williamset al. 2000), whichare already well serviced by birds including silvereyes. Possums can disperse the seeds of small-fruited plants (Williams et al. 2000; Dungan et al. 2002), but have been tested on only one large-seeded plant, miro (Prumnopitysferruginea), which they did not swallow. Pigs (Sus scrofa) eat and destroy large numbers of the seeds of some native plants such as tawa (Beilschmiedia tawa), hinau (Elaeocarpus dentatus; Thomson and Challies 1988) and matai (Prumnopitys taxifolia; Cochrane 1994, p. 28), but there are no data on whether any seeds survive to germinate from the dung. Information is also lacking on other large mammals such as goats (Capra hircus), sheep (Ovis aries), horses (Equus caballus), and cattle (Bos taurus), which could potentially provide some dispersal of largeseeded native plants; this warrants further investigation.

The major change in bird-plant mutualisms since human arrival is not a transition from natives to exotic species, but the shift from endemics to the silvereye, which has replaced declining or extinct endemics such as stitchbirds, saddlebacks, and (in Northland) bellbirds. The silvereye is now the most important mutualist, present through $80 \%$ of the country, compared with $45-55 \%$ for tui, bellbirds and kereru (Bull et al. 1985), and responsible for $38 \%$ of all fruit visits and $31 \%$ of all flower visits to native plants. On flower and fruit visits combined, silvereyes are $35 \%$ more important numerically than bellbirds, twice as important as tui, and more than three times as important as kereru. The previous conclusions by Clout and Hay (1989), Lee et al. (1991) and Lord et al. (2002) - that kereru are the most important seed disperser in New Zealand forests - are true only for the small number of largeseeded, fleshy-fruited species in the flora (e.g., miro). The decline of kereru in parts of New Zealand threatens the dispersal of these large fruits (Clout et al. 1995). It is clear from this review that exotic bird species have done very little to help replace declining endemics.

The fewer available data on insect visits to flowers suggest a greater shift toward exotic insects, with slightly more than a quarter of visits made by exotics. Surprisingly, given that Apis mellifera is the consummate insect pollinator and is one of New Zealand's commonest insects, other hymenopterans (Bombus, Vespula) were often more frequent flower-visitors. This trend may increase, as the spread of the varroa mite is expected to reduce feral honeybee numbers (Goodwin 2004).

In conclusion, considering all introduced animals together, their contribution to plant-animal mutualisms with native plants in New Zealand appears to be surprisingly small. 
Acknowledgements We thank Victoria Burgess, Alison Beath, and Paul Peterson for help with fieldwork, Claire Murphy for unpublished data, and the Public Good Science Fund for financial support. Ian Atkinson, George Cheely, John Innes and Bill Lee commented on earlier versions of the manuscript and helped to improve it considerably.

\section{References}

Anderson SH (1997)Changes in native ecosystem processes: the dynamics of pollination and dispersal in New Zealand forests. MSc Thesis, Auckland University, Auckland, New Zealand

Anderson SH (2003) The relative importance of birds and insects as pollinators of the New Zealand flora. NZ J Ecol 27:83-94

Anderson SH, Kelly D, Robertson AW, L adle JJ,Innes JG (2006) Birds as pollinators and dispersers: a case study from New Zealand. Acta Zool Sinica (in press)

Atkinson IAE, Millener PR (1991) An ornithological glimpse into New Zealand's prehuman past. Acta XX Congr Int Ornithol I: 129-192

Bell BD (1991) Recent avifaunal changes and the history of ornithology in New Zealand. Acta XX Congr Int Ornithol I: 195-230

Bocher J, Philipp M (1985) Aspects of the reproductive biology of Mimulus repens (Scrophulariaceae) at Lake Ellesmere, Canterbury, New Zealand. NZ J Bot 23: 141-149

Bull PC, Gaze PD, Robertson CJR (1985) The atlas of bird distribution in New Zealand. Ornithological Society of New Zealand, Wellington, New Zealand

Burrows CJ (1994) Fruit types and seed dispersal modes of woody plants in Ahuriri Summit Bush, Port Hills, western Banks Peninsula, Canterbury, New Zealand. NZ J Bot 32: 169-181

Butz Huryn VM (1995) Use of native New Zealand plants by honeybees (Apis mellifera L.): a review. NZ J Bot 33: 497-512

Clout MN, Hay JR (1989) The importance of birds as browsers, pollinators and seed dispersers in New Zealand forests. NZ J Ecol suppl $12: 27-33$

Clout MN, Karl BJ, Pierce RJ, Robertson HA (1995) Breeding and survival of New Zealand Pigeons Hemiphaga novaeseelandiae. Ibis 137: 264-271

Cochrane CH (1994) Vegetation assessment and its implications for feral goat management in Isolated Hill Scenic Reserve, southern Marlborough. MSc Thesis, University of Canterbury, Christchurch, New Zealand

Cox PA (1983) Extinction of the Hawaiian USA avifauna resulted in a change of pollinators for the Ieie Freycinetia arborea. Oikos 41: 195-199

Cox PA, Elmqvist T (2000) Pollinator extinction in the Pacific Islands. Conserv Biol 14: $1237-1239$

Daniel MJ (1976) Feeding by the short-tailed bat (Mystacina tuberculata) on fruit and possibly nectar. NZ J Zool 3: 391-398

Delph LF, Lively CM (1985) Pollinator visits to floral colour phases of Fuchsia excorticata. NZ J Zoo1 12: 599-603

Donovan BJ (1980) Interactions between native and introduced bees in New Zealand. NZ J E c ه::1104-116

Dugdale JS (1975) The insects in relation to plants. In: Kuschel G (ed) Biogeography and ecology in New Zealand. Junk, The Hague, pp 561-589

Dungan RJ, O'Cain MJ, Lopez ML, Norton DA (2002) Contribution by possums to seed rain and subsequent seed germination in successional vegetation, Canterbury, New Zealand. NZ J Ecol 26: 121-128 
Ecroyd CE (1996) The ecology of Dactylanthus taylorii and threats to its survival. NZ J E c 20: 81-100

Eifler DA (1995) Patterns of plant visitation by nectar-feeding lizards. Oecologia 101: 228-233

Godley EJ (1979) Flower biology in New Zealand. NZ J Bot 17: 441-466

Goodwin M (2004) Introduction and spread of varroa in New Zealand. Bee World 85: 26-28

Heather BD, Robertson HA (1996) The field guide to the birds of New Zealand. Viking, Auckland, New Zealand

Holdaway RN (1999)Introduced predators and avifaunal extinction in New Zealand. In: MacPhee RDE (ed) Extinctions in near time: causes, contexts, and consequences. Advances in Vertebrate Paleobiology. Kluwer Plenum, New York, pp 189-238

Irwin RE, Brody AK (1999) Nectar-robbing bumble bees reduce the fitness of Ipomopsis aggregata (Polemoniaceae). Ecology 80:1703- 1712

Janzen DH (1974) The deflowering of Central America. Nat Hist 83: $48-53$

Kearns CA, Inouye DW, Waser NM (1998) Endangered mutualisms: the conservation of plant-pollinator interactions. Annu Rev Ecol Syst 29: 83-112

Kelly D, Ladley JJ,Robertson AW (2004) Is dispersal easier than pollination?Twotests in New Zealand Loranthaceae. NZ J Bot 42: 89-103

Ladley JJ (1994) The reproductive ecology of the Loranthaceae mistletoes of New Zealand. MSc Thesis, University of Canterbury, Christchurch, New Zealand

Ladley JJ, Kelly D, Robertson AW (1997) Explosive flowering, nectar production, breeding systems, and pollinators of New Zealand mistletoes (Loranthaceae). NZ J Bot 35: 345-360

Lee WG, Clout MN, Robertson HA, Wilson JB(1991) Avian dispersers and fleshy fruits in New Zealand. Acta XX Congr Int Ornithol III: 1617-1623

Lloyd BD (2001) Advances in New Zealand mammalogy 1990-2000: short-tailed bats. J R S o NZ 31: 59-81

Lord JM (1991) Pollination and seed dispersal in Freycinetia baueriana, a dioecious liane that has lost its bat pollinator. NZ J Bot 29: 83-86

Lord JM, Markey AS, Marshal1 J (2002) Have frugivores influenced the evolution of fruit traits in New Zealand? In: Levey DJ,Silva WR, Galetti M (eds) Seed dispersal and frugivory: ecology, evolution and conservation. CABI, Wallingford,pp 55-68

McConkey KR, Drake DR (2002) Extinct pigeons and declining bat populations: are large seeds still being dispersed in the tropical Pacific? In: Levey DJ, Silva WR, Galetti M (eds) Seed dispersal and frugivory: ecology, evolution and conservation. CABI, Wallingford,pp 381-395

McNutt KL (1998) Impacts of reduced bird densities on pollination and dispersal mutualisms in New Zealand forests. MSc Thesis, Massey University, Palmerston North, New Zealand

Meehan HJ, McConkey KR, Drake DR (2002) Potential disruptions to seed dispersal mutualisms in Tonga, Western Polynesia. J Biogeogr 29: 695-712

Montgomery BR, Kelly D, Ladley JJ (2001) Pollinator limitation of seed set in Fuchsia perscandens (Onagraceae) on Banks Peninsula, South Island, New Zealand. NZ J Bot 39: 559-565

Murphy CL (1996) The impact of honeybees on montane ecosystems within Tongariro National Park. MSc Thesis, Massey University, Palmerston North, New Zealand

O'Donnell CFJ, Dilks PJ (1994) Foods and foraging of forest birds in temperate rainforest, South Westland, New Zealand. NZ J Ecol 18: 87-107

Paton DC (1993) Honeybees in the Australian environment: does Apis mellifera disrupt or benefit the native biota? Bioscience 43: 95-103 
Primack RB (1978) Variability in New Zealand montane and alpine pollinator assemblages. NZ J Ecol 1:66-73

Primack RB (1979) Reproductive biology of Discaria toumatou (Rhamnaceae). NZ J Bot 17:9-13

Primack RB (1983) Insect pollination in the New Zealand mountain flora. NZ J Bot 21: 317-333

Rainey WE, Pierson ED, Elmqvist T, Cox PA (1995) The role of flying foxes (Pteropodidae) in oceanic island ecosystems of the Pacific. In: Racey PA, Swift SM (eds) Ecology, evolution and behaviour of bats. Claredon Press, Oxford, pp 47-62

Robertson AW, Kelly D, Ladley JJ, Sparrow AD (1999) Effects of pollinator loss on endemic New Zealand mistletoes (Loranthaceae).Conserv Biol 13: 499-508

Robertson AW, Ladley JJ,Kelly D (2005) The effectiveness of short-tongued bees as pollinators of apparently "ornithophilous" New Zealand mistletoes. Aust Ecol 30: 298-309

Sekercioglu CH, Daily GC, Ehrlich PR (2004) Ecosystem consequences of bird declines. Proc Natl Acad Sci USA 101: 18042-18047

Steadman DW (1995) Prehistoric extinctions of Pacific Island birds: biodiversity meets zooarchaeology Science 267:1123-1131

Steadman DW (1997) The historic biogeography and community ecology of Polynesian pigeons and doves. J Biogeogr 24: 737-753

Thomson C, Challies CN (1988) Diet of feral pigs in the podocarp-tawa forests of the Urewera Ranges. NZ J Ecol 11: 73-78

Tisch PA (1996) Masting: a test of the pollination efficiency and predator satiation hypotheses. MSc Thesis, University of Canterbury, Christchurch, New Zealand

Towns DR, Daugherty CH, Cree A (2001) Raising the prospects for a forgotten fauna: a review of 10 years of conservation effort for New Zealand reptiles. Biol Conserv 99: 3-16

Whitaker AH (1987) The roles of lizards in New Zealand plant reproductive strategies. NZ J Bot 25: 315-328

Williams PA, Karl BJ (1996) Fleshy fruits of indigenous and adventive plants in the diet of birds in forest remnants, Nelson, New Zealand. NZ J Ecol 20: 127-145

Williams PA, Karl BJ, Bannister P, Lee WG (2000) Small mammals as potential seed dispersers in New Zealand. Aust Ecol 25: 523-532

Wotton DM (2002) Effectiveness of the common gecko (Hoplodactylus maculatus) as a seed disperser on Mana Island, New Zealand. NZ J Bot 40: 639-647 